\title{
Research into Educational Management in Portugal: Themes, Focus and Methodologies*
}

\section{Leonor L. Torres - Licínio C. Lima}

Universidade do Minho - Braga - Institute of Education (Portugal)

doi: 10.7358/ecps-2015-011-torr

leonort@ie.uminho.pt

llima@ie.uminho.pt

\section{RICERCA SULL'AMMINISTRAZIONE SCOLASTICA \\ IN PORTOGALLO: TEMI, PUNTO FOCALE E METODOLOGIE}

\begin{abstract}
Today, educational management is an expanding scientific field that has been attracting ever more social and political visibility, and it has been the object of a considerable amount of research. In the Portuguese context, over the past two decades there has been a sharp movement to create post-graduate courses, to increase individual and collective research and the number of scientific publications. The growing centrality assumed by the sociological approaches of educational organisations, associated with a vast collection of scientific research and publications, promoted a meta-analysis of a considerable amount of work produced in this area. For this analysis, we selected 80 dissertations all presented within the context of the pioneering Master's course, and the oldest course in the country on educational management, the Master in "Education Sciences", specialising in "Educational Management", offered by the University of Minho. Of the main trends identified, the most important were: (i) synchronization between the political agenda, professional experience and research interests; (ii) use of a certain theoretical pluralism, mobilizing two or more models of organizational analysis; (iii) the use of a largely qualitative methodology, tending towards the case study method; (iv) mobilizing a meso-approach to school organization, seeking to coordinate micro and macro analytical levels. On a more substantive plane, this
\end{abstract}

* This work received support from National Funds through the FCT (Fundação para a Ciência e a Tecnologia), within the context of the project PEst-OE/CED/UI1661/2014 of the CIEd-UM. 
study has contributed to discussions on some dilemmas and agendas that, in our opinion, are involved in constructing the object of educational management.

Keywords: Analytical and interpretative approaches, Educational management, Meta-research, Normative and prescriptive perspectives, School as an educational organization.

\section{InTRODUCTION}

Educational management is currently an area of study affected by tension between opposing vocations and theoretical-disciplinary affiliations: prescriptive and normative approaches, concerned with formulas to correctly organise and manage the school, and analytical and interpretative approaches, focused on understanding social and organizational processes and dynamics. The difficult dialogue between the two perspectives, as well as incipient reflexivity within each of them, have not encouraged a deeper and broader understanding of educational management and a revised concept for it. Over the past two decades a line of research has been developing that has had a particular effect on Portuguese reality and which is rooted in a sociological, organisational approach to the school. The resulting research has increased and diversified significantly and merits special attention.

The principal objective of this research lies, firstly, in making a survey of themes, theoretical focus and methodological strategies adopted by the authors of 80 dissertations presented within the context of the pioneering Master's course, and the oldest one in the country in educational management - the Master in Education Sciences, specialising in Educational Management, administered by the University of Minho. Secondly, theoretical and methodological trends are identified leading to reflection on some of the dilemmas and agendas involved in constructing the educational management object.

\section{Methodology}

The methodology used in this study rests basically on an analysis of the content of the dissertations. To detect dominant trends and, at the same time, some significant associations among the variables, we used a grid that covers 
several categories and dimensions, and this guided us in selecting information on the themes selected, theoretical perspectives and the methodology adopted by the authors, besides other more substantive data related to the results and conclusions of the research work. Quantitative information was introduced in the SPSS statistical programme to help extract some important trends likely to be included in a more extensive, diachronic approach. In parallel to this, more intensive and synchronic analyses were carried out, focusing more particularly on the content of each dissertation, trying where possible to understand the main theoretical and empirical contributions of educational management.

\section{RESEARCH TRENDS: A META-ANALYTICAL APPROACH TO SCIENTIFIC PRODUCTION}

Created in 1986 and referred to as the Master in Education specialising in School Management, this was a pioneer course in Portugal in educational sciences and ran for the 14th time in the 2013/2014 school year. Over the past two decades, 80 dissertations have been presented, irregularly, over this period, although increasing sharply from the year 2000 (Figure 1).

Most authors of dissertations were men (59\%), which may reflect the male ethos associated with positions in management and administration, particularly in upper management, in Portuguese schools. Despite there being a large number of women on the teaching staff, the fact is that male teachers tend to manage schools more frequently, releasing intermediate management positions to female teachers (Figure 2).

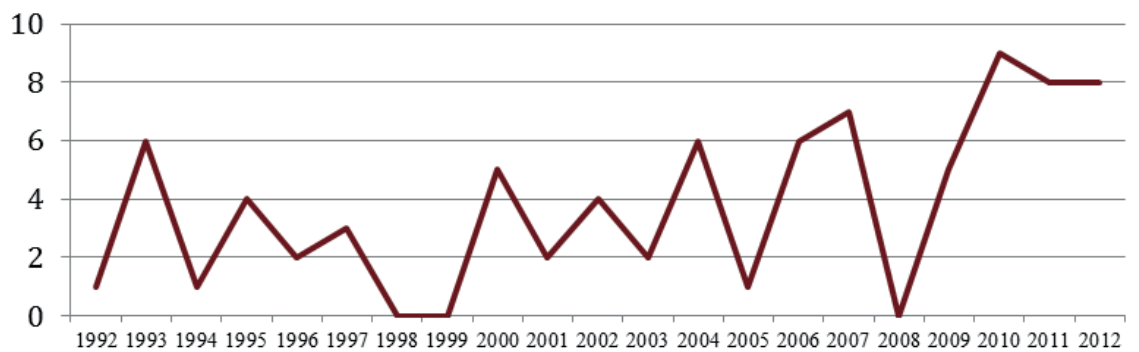

Figure 1. - Increase in the number of dissertations concluded (1992-2012).

Source: Archive of the Educational Sciences Library of the Education Institute of the University of Minho. 


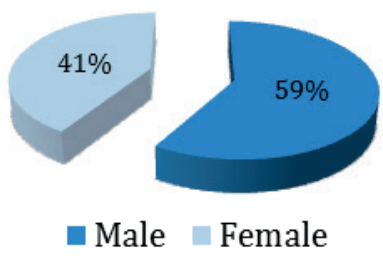

Figure 2. - Teacher gender.

Source: Master's dissertations in the "Educational Sciences» specialising in "Educational Management» (1992-2012).

The dissertations analysed differ in their degree of theoretical and methodological detail, and their formal structure varies over the years. Table 1 shows quantitative indicators for the scale, volume and nature of reference sources, and for the different research techniques. Findings reveal: (i) a considerable volume of dissertations (an overall average of 230 pages); (ii) strong bibliographic back-up (an average of 147 bibliographic references); (iii) various research techniques (an average of 3 techniques); (iv) good methodological support ( $8 \%$ of the bibliographical references address methodology).

Table 1. - Profile of dissertations in "Educational Management».

Source: Master's dissertations in the "Educational Sciences" specialising in "Educational Management» (1992-2012).

\begin{tabular}{lccc}
\hline & Minimum & Maximum & Average \\
\hline Total nr. of pages & 83 & 451 & 233 \\
Total nr. of pages of bibliography & 5 & 35 & 13 \\
Nr. bibliographic references & 39 & 351 & 150 \\
Nr. theoretical models & 1 & 7 & 2 \\
Nr. research techniques & 1 & 5 & 3 \\
Nr. references to methodology & 2 & 38 & 12 \\
Nr. organisations studied & 1 & 7 & 1 \\
Nr. stakeholders studied & 0 & 7 & 3 \\
\hline
\end{tabular}

\section{RESEARCH THEMES AND PROBLEMS}

Using the list of themes stated in the dissertations, we built up our list of themes to help consolidate information and arrange it in theoretical and conceptual terms. This led to establishing eleven distinct themes on three levels: (i) scale of analysis (macro-meso-micro); (ii) object of study; (iii) theoreti- 
cal and empirical focus (political systems, school organisation, management structures, stakeholders, projects).

The results in Table 2 show a preference for the themes of autonomy and democratic governance of schools/clusters (26.3\%), followed immediately by leadership processes and upper and intermediate management (20\%). If we add to these preferred areas the third most preferred theme - processes for innovation and organisational change (12.5\%), we can conclude that most of the themes addressed (around 60\%) deal with structures of governance, management and leadership for schools/clusters.

A cross-analysis of the different themes reveals a clear concern for the process of democratization in the education system, and a research agenda strongly associated with the dominant political agenda in different histori$\mathrm{cal}$ and educational situations is very evident. Although it is a fact that the problems of democratising education management form the backbone of all the dissertations, the way in which this is perceived from the theoretical and empirical point of view changes, particularly, from the end of the 1990 s, when it moves from a meso-analytical focus, centred on regulating the education system, to focussing on meso-analysis, more concerned with the diversity of organisational and administrative phenomena in education.

Table 2. - Themes in "Educational Management». Source: Master's dissertations in the "Educational Sciences" specialising in "Educational Management» (1992-2012).

\begin{tabular}{lrr}
\hline \multicolumn{1}{c}{ THEMEs } & NR. & $\%$ \\
\hline 1. Educational reform, organisation of the education system & 6 & 7.5 \\
2. Training, participation and professional identity of teachers & 5 & 6.3 \\
3. Training in the non-school context & 4 & 5.0 \\
4. Organisational culture of schools / institutes of education & 4 & 5.0 \\
5. Innovation and organisational change & 10 & 12.5 \\
6. Parent associations, participation of parents in school & 4 & 5.0 \\
7. Organisational participation of other stakeholders in education & 5 & 6.3 \\
8. Leadership and intermediate management & 8 & 10.0 \\
9. Leadership and upper management: the role of the director, & 8 & 10.0 \\
school board & & 6.3 \\
10. Daily issues, labour relations, communication and environment & 5 & 26.3 \\
in school context & 21 & 100.0 \\
\hline 11. Autonomy and democratic governance of schools/clusters & 80 &
\end{tabular}


This change of view also follows international research trends in educational management (cfr., for example, theoretical summaries by Derouet, 1987 and 2000; Lima, 1992 and 1995; Maroy, 1992; Dutercq, 2000; Barroso, 2002) that prefer an analysis of organisation, contexts and stakeholders. However, changes in research interests cannot overlook the actual social, political and academic contexts in which they occur: on the one hand, the influence of educational policies and reforms implemented and their media impact, and, on the other, the actual institutional and academic context of post-graduate training.

Figure 3 illustrates the close relationship between the research agenda present in the dissertations and the political agenda that prevailed in certain years, in the form of legislative measures introduced. The 1990s, affected by the approval of the Basic Law on the Education System (LBSE) (1986) and by other changes to the structure of central administration and the management model for schools, promoted the study of processes for developing reform, innovation and change, as well as their impact on redefining the professional identity of teachers and on the organisational culture of the school.

- Law nr. 46/86 (LBSE)

- DL nr. 43/89 (Autonomy)

- DL nr. 286/89

(Area-School)

- DL nr. 172/91

(New management model)

- Ruling nr. 98-A/92

(Pupil assessment)

- DL nr. 133/93

(Min. Ed. Organic Law)

$1990 \mathrm{~s}$
- DL nr. 115-A/98

(Autonomy scheme)

- DL nr. 6/2001

(Flexible curricular management)

- DL nr. 7/2003

(Municipal Boards

of Education)

- Ruling nr. 13 313/2003

(School clusters)

Turn of century

- DL nr. 75/2008

(Director)

- DL nr. 104/2008

(Licensed teacher)

- Ruling nr. 12591

(Full time school)
- Training, participation and professional identity for teachers.

- Organisational culture of schools/educational institutions.

- Innovation and organisational change (Area-School, Pupil assessment).

- Leadership and intermediate management.
- Autonomy and democratic governance of school/cluster.

- Parent associations, parent participation in school.

- Organisational participation of other educational stakeholders.

- Innovation and organisational change (Flexible curriculum management, Education charter).
Last decade

- Leadership and top management: role of director, board.

- Leadership and intermediate management.

- Innovation and organisational change (Licensed teachers, Full time school).

Figure 3. - Political agenda and research agenda. 
Right at the turn of the century, when the scheme for school autonomy was regulated and the competencies of Municipal Education Boards defined, the major issues of autonomy and democratic governance, parent associations and parent participation become apparent, as does an interest in examining the impact of some educational innovation measures (Flexible curriculum management and the Education charter, amongst others).

However, in the past decade there has been an even more obvious connection between the political and research fields. Implementing the individual management model, associated with strong and effective leadership, and selfassessment and external school assessment mechanisms, gave rise, almost all at the same time, to the interest in examining upper and intermediate leadership.

If empirical evidence suggests the imposition of themes by the political agenda, a more thorough analysis of the content of dissertations reveals the importance of the institutional and academic context in the theoretical construction of the study object. The scientific capital accumulated over recent years on educational management, materialising in a number of publications from teachers and researchers of the University of Minho, opened and extended the field of research, which was decidedly theoretical and analytical, that then consolidated the sociological approach of educational organisations (Lima, 1992). The scope of the Master's course fits clearly into this context of scientific development, benefiting and contributing towards widening reflections and research gradually developing in each cycle. We shall now look at the way this scientific and disciplinary context has had an effect on the theoretical construction of the study object.

\section{THEORETICAL FOCUS}

Seeking to avoid a prescriptive training model subject to the technical, regulatory and practical issues of educational management, the fourteen years in which the course was administered sustained their teaching dynamics on the sociological approach of educational organisations, preferring a multi-paradigmatic analysis of the diversity of the organisational and administrative phenomena of education. Taking the school universe as the object of the study, several theoretical views and analysis models were examined (critically) (Ellström, 1983; Bush, 1986; Morgan, 1986), centring the debate on a multi-analysis of the rationalities, authorities, objectives and strategies of the stakeholders in context.

An analysis of the dissertations shows us that the vast majority, regardless of the theme selected, base their theoretical and empirical analysis on more than one analysis model $(70 \%)$. Rational-bureaucratic, political and 
ambiguity models are most used in research, thus confirming the need to pick up both normative regularities and processes of discontinuity, that is, the different logics and rationalities that clash in dealing with school issues (Figure 4).

Secondly, we try to identify the models combined most frequently to understand the actual theoretical and methodological structure of the dissertations and the scope of heuristic results. Figure 5 illustrates the three combinations preferred by the authors: firstly, the rational-bureaucratic model combined with the political model; secondly, the adoption of the cultural model as a unique perspective; and thirdly, the three-pronged analysis including rational-bureaucratic, political and ambiguity models.

Despite the different degrees of theoretical and conceptual detail, many of the dissertations attempted a meso-approach to school organisations, focusing on an analysis of the different action contexts, as the locus of confluence for other rationalities and guidelines external and internal to the school.

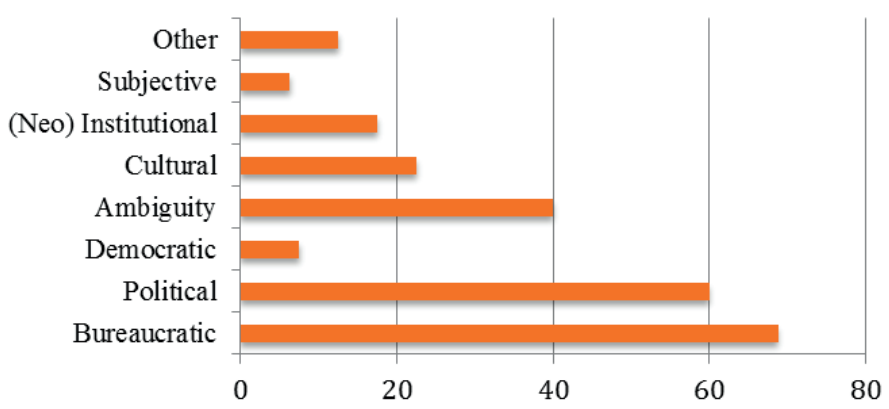

Figure 4. - Theoretical models adopted. Source: Master's dissertations in the "Educational Sciences" specialising in "Educational Management" (1992-2012).

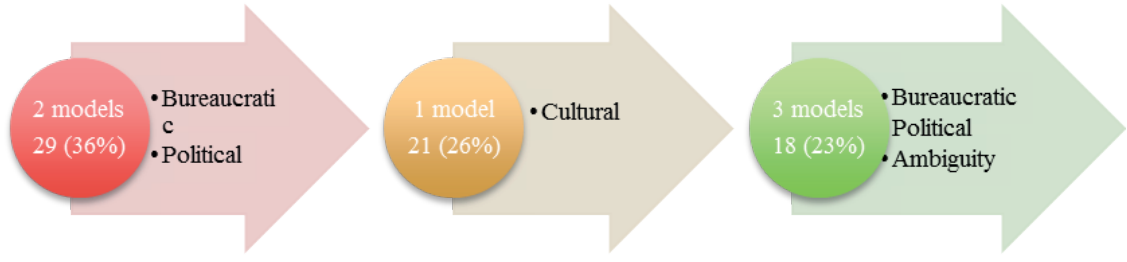

Figure 5. - Combinations of models. Source: Master's dissertations in the "Educational Sciences» specialising in "Educational Management» (1992-2012). 


\section{Methodological Strategies}

Choosing the school as the study object and considering the multi-dimensional aspect of organisational processes, therefore, requires constructing a methodological approach to establish the different facets of the phenomenon. It is not surprising, therefore, that almost all the dissertations adopted the qualitative research paradigm as the reference framework (Figure 6) for the case study observation method (Bogdan \& Biklen, 1994) (Figure 7).

The focus of studies on specific educational organisation and, within this, in specific contexts and structures, demanding the selection of specific stakeholders, leads to a case study restricted in characteristics and scope. The data in Table 3 illustrate precisely what the nature and scale of observation in these case studies are: most address a single organisation (75\%), the prevalence being school clusters and state basic and secondary schools (65\%), the radius of observation restricted to management bodies and structures $(60 \%)$ and to the stakeholders directly involved in them - the managers $(81.3 \%)$ and the teachers $(76.3 \%)$.

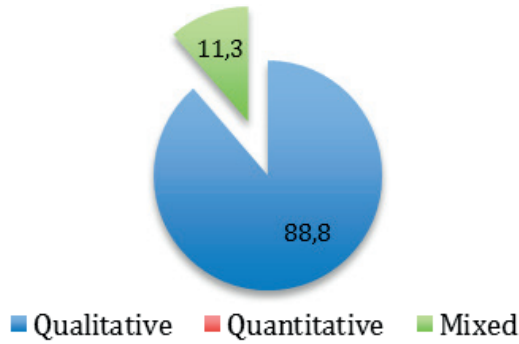

Figure 6. - Methodology. Source: Master's dissertations in the "Educational Sciences» specialising in "Educational Management» (1992-2012).

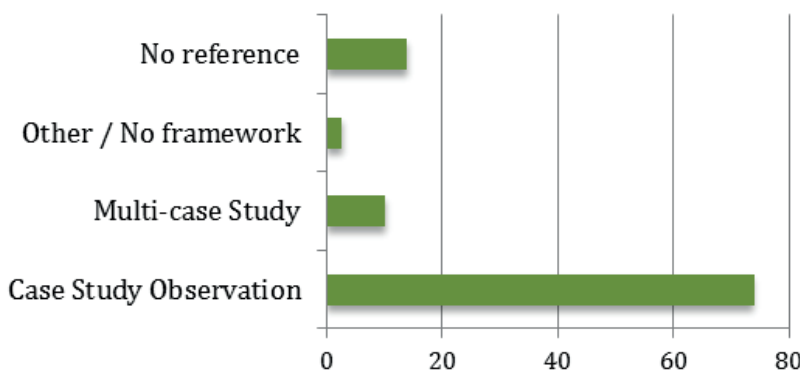

Figure 7. - Research methods. Source: Master's dissertations in the "Educational Sciences» specialising in "Educational Management» (1992-2012). 
Table 3. - Characteristics and scope of case studies. Source: Master's dissertations in the "Educational Sciences» specialising in "Educational Management» (1992-2012).

\begin{tabular}{|c|c|c|c|c|c|c|c|}
\hline $\begin{array}{c}\text { TyPE } \\
\text { OF } \\
\text { ORGANISATION }\end{array}$ & $\%$ & $\begin{array}{c}\text { Number } \\
\text { OF } \\
\text { ORGANISATIONS }\end{array}$ & $\%$ & $\begin{array}{c}\text { STRUCTURES/ } \\
\text { SizE }\end{array}$ & $\%$ & Players & $\%$ \\
\hline $\begin{array}{l}\text { Higher } \\
\text { Education }\end{array}$ & 3.8 & $\begin{array}{c}1 \\
\text { organisation }\end{array}$ & 75 & $\begin{array}{l}\text { Upper management } \\
\text { bodies }\end{array}$ & 25 & Managers & 81.3 \\
\hline $\begin{array}{l}\text { Sec. state } \\
\text { school }\end{array}$ & 17.5 & $\begin{array}{c}2 \\
\text { organisations }\end{array}$ & 5 & $\begin{array}{c}\text { Intermediat } \\
\text { management bodies }\end{array}$ & 7.5 & Teachers & 76.3 \\
\hline $\begin{array}{c}\text { Basic } \\
\text { state school }\end{array}$ & 20 & $\begin{array}{c}4 \\
\text { organisations }\end{array}$ & 3.8 & $\begin{array}{c}\text { Environment / } \\
\text { School daily routine }\end{array}$ & 7.5 & Pupils & 26.3 \\
\hline $\begin{array}{l}\text { 1st C school / } \\
\text { Infant }\end{array}$ & 5 & $\begin{array}{c}6 \\
\text { organisations }\end{array}$ & 1.3 & $\begin{array}{l}\text { Management bodies } \\
\text { (all) }\end{array}$ & 27.5 & $\begin{array}{l}\text { Country/ } \\
\text { EE }\end{array}$ & 30 \\
\hline Private school & 2.5 & $\begin{array}{c}7 \\
\text { organisations }\end{array}$ & 1.3 & $\begin{array}{l}\text { Programme/ } \\
\text { Project }\end{array}$ & 12.5 & Community & 16.3 \\
\hline $\begin{array}{c}\text { Prof. / } \\
\text { Artistic school }\end{array}$ & 2.5 & $\begin{array}{c}\text { Not } \\
\text { applicable }\end{array}$ & 12.5 & $\begin{array}{c}\text { Not } \\
\text { applicable }\end{array}$ & 10 & $\begin{array}{l}\text { Central } \\
\text { Admin. }\end{array}$ & 7.5 \\
\hline $\begin{array}{c}\text { Other } \\
\text { education orgs. }\end{array}$ & 8.8 & & & $\begin{array}{c}\text { Management } \\
\text { \& environ bodies }\end{array}$ & 6.3 & Non-teaching & 22.5 \\
\hline $\begin{array}{l}\text { School } \\
\text { clusters }\end{array}$ & 27.5 & & & $\begin{array}{l}\text { Management } \\
\& \text { project body }\end{array}$ & 3.8 & $\begin{array}{c}\text { Other } \\
\text { stakeholders }\end{array}$ & 5.2 \\
\hline $\begin{array}{l}\text { Various types } \\
\text { of org. }\end{array}$ & 5 & & & & & & \\
\hline $\begin{array}{c}\text { Not } \\
\text { applicable }\end{array}$ & 7.5 & & & & & & \\
\hline
\end{tabular}

The timing (one school year) and scope (one body, structure or project) of research demanded the use of several research techniques to detect phenomena from different viewpoints. On average, empirical research used three instruments (38\%), and around 35\% used four. A small number of research projects $(7 \%)$ used only one research technique - analysis of documents, used intensively in macro-analytical approaches, the core objective of which (e.g. educational reform, organisation of the education system, education policies) involved the analysis of a wide range of legislation, speeches and other types of document (Figure 8).

Apart from an analysis of documents, researchers also used interview and observation techniques. In fact, a significant number of dissertations opted for this triple combination: an analysis of documentation, mainly legislation and documents on organisation; the semi-structured interview of 
managers and teachers; and non-participating observation in schools, namely at meetings of the different bodies involved and of the school administrative office. The questionnaire appears almost always as the complementary technique to all the others, and its use has clearly increased in recent years.

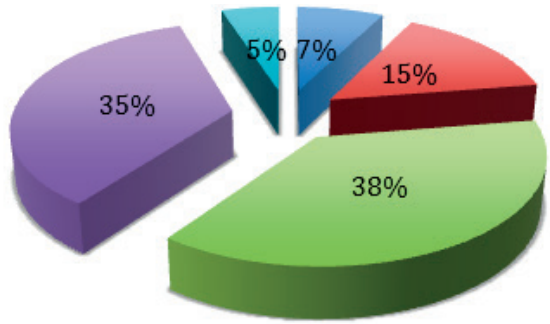

$\varpi 1$ technique $\square 2$ techniques $\square 3$ techniques $₫ 4$ techniques $\square 5$ techniques

Figure 8. - Number of research techniques. Source: Master's dissertations in the "Educational Sciences» specialising in "Educational Management» (1992-2012).

\section{CONCLUSION}

Preliminary research data suggests a scientifically based, post-graduate training project, giving priority to the theoretical and empirical interpretation of the realities of educational organisation and administration in Portugal and in other Portuguese speaking countries. Based on these options, a break was made with the judicial and legislative tradition that prevailed in training in Educational Management in Portugal throughout almost the whole of the twentieth century, and prescriptive approaches, centred mainly on managerial type training and geared only to upper management, were rejected.

The multiplicity of theory and methodology expressed in the Master's dissertations is based on a critical understanding of the most relevant sociological approaches to educational organisation and educational management, within the context of which, throughout the past three decades, most Portuguese researchers still working in the country's different universities and polytechnic colleges, received their training.

Although research themes reveal a close proximity to the priorities covered in government programmes, a situation that is not institutionally inferred by management of the Master's degree and that seems to reduce room for autonomy in the agendas of researchers, this aspect should be seen against professional interests mainly assumed by learners, the majority being intermediate directors and managers in Portuguese schools. 
The meta-research conducted on the collection of dissertations proved that there is still a prevalence of qualitative methodology, using the case study method, supported on a mix of different research techniques: documentary analysis, interviewing, surveys by questionnaire and observation. This eminently interpretative methodological strategy led to an approximation of the different logics and rationalities found throughout school organisation, also helping to sustain a meso-approach based on coordination between macro and micro analyses.

\section{REFERENCES}

Barroso, J. (2002). Research into the school: Contributions of educational management. Investigar em Educação, 1(1), 277-325.

Bogdan, R. C., \& Biklen, Sari (1994). Investigação qualitativa em educação. Uma introdução à teoria e aos métodos. Porto: Porto Editora.

Bush, T. (1986). Theories of educational management. London: Harper \& Row.

Derouet, J. L. (1987). A sociology of schools: The problems of constructing a new scientific object. Revue Française de Pédagogie, 78, 86-108.

Derouet, J. L. (2000). Presentation. Is a school management science possible? Reflections on the movement of knowledge between research, politics and management. Revue Française de Pédagogie, 130, 5-14.

Dutercq, Y. (2000). Educational management: New context, new perspectives. Revue Française de Pédagogie, 130, 143-170.

Ellström, P. E. (1983). Four faces of educational organizations. Higher Education, 12, 231-241.

Lima, L. C. (1992). Educational organisations and educational management. Revista Portuguesa de Educą̧ão, 5(3), 1-8.

Lima, L. C. (1995). Building an object: A critical analysis of Portuguese research into the school. In A. Estrela, J. Barroso, \& J. Ferreira (Coords.), A escola, um objecto de estudo (pp. 10-28). Lisboa: AFIRSE - FPCE.

Maroy, C. (1992). The school in the light of the sociology of organisations. Education Formation, 228, 27-50.

Morgan, G. (1986). Images of organization. Beverly Hills: Sage. 


\section{RiassunTo}

L'amministrazione scolastica rappresenta oggi un campo scientifico in espansione, con un notevole dinamismo a livello di ricerca ed una crescente visibilità sociale e politica. Nel contesto della realtà portoghese si è osservato, nell'ultimo ventennio, il proliferare di corsi post-laurea, un aumento della ricerca individuale e collettiva ed un maggior numero di pubblicazioni scientifiche. La crescente centralità assunta dagli approcci sociologici alle organizzazioni educative, associata alle numerose ricerche e pubblicazioni scientifiche, ha permesso di sviluppare una meta-analisi su un insieme di opere prodotte in questo campo. Abbiamo selezionato ed analizzato 80 tesi svolte nell'ambito della laurea specialistica pioniera e piu antica del Paese nel campo della amministrazione scolastica - la laurea specialistica in "Scienze dell'Educazione», specializzazione in "Amministrazione Scolastica" presso l'Università del Minho (ufficialmente Universidade do Minho). Tra le principali tendenze individuate emergono: (i) la sincronia tra agenda politica, esperienze professionali ed interessi di ricerca; (ii) l'adesione ad un certo pluralismo teorico, mobilitando due o più modelli di analisi organizzativa; (iii) l'uso di una metodologia prevalentemente qualitativa, concentrata sul metodo dello studio di caso; (iv) la mobilitazione di un meso-approccio dell'organizzazione scolastica, volto ad articolare i livelli di analisi micro e macro. Su un piano piu sostanziale, questo studio ha inoltre contribuito alla discussione intorno ad alcuni dilemmi e questioni che, dal nostro punto di vista, si ricollegano alla definizione del ruolo dell'amministrazione scolastica.

Parole chiave: Amministrazione scolastica, Approcci analitici e interpretativi, Meta-ricerca, Prospettive normative e prescrittive, Scuola come organizzazione educativa. 